\title{
Penerapan Model Problem Based Learning untuk Meningkatkan Kemampuan Memahami Perkalian Bilangan
}

\author{
Eny Handayani
}

SDN Kepanjenkidul 2 Kota Blitar

Email: enyhandayani@yahoo.com

\begin{tabular}{l}
\hline Tersedia Online di \\
\hline http://www.jurnal.unublitar.ac.id/ \\
index.php/briliant \\
\hline \\
\hline Sejarah Artikel \\
\hline Diterima pada 29 Juni 2017 \\
Disetuji pada 10 Juli 2017 \\
Dipublikasikan pada: 2 Agustus \\
2017 Hal 319-327 \\
\hline
\end{tabular}

Kata Kunci:

matematika, problem based learning

\begin{abstract}
Abstrak: Pengamatan belajar matematika di kelas dua menunjukkan bahwa hanya $40 \%$ yang mengerti, sementara $60 \%$ siswa lainnya belum mengerti tentang perkalian. Penelitian yang digunakan adalah Class Action Research yang terdiri dari 4 tahap. Ada rencana, implementasi, observasi, dan refleksi. Penelitian ini bertujuan untuk meningkatkan kemampuan siswa kelas II dalam memahami perkalian melalui Model Pembelajaran Berbasis Masalah. Penerapan Model Pembelajaran Berbasis Masalah dalam pembelajaran matematika dapat meningkatkan kemampuan siswa dalam memahami perkalian Nilai rata-rata siswa meningkat secara bertahap dari siklus tinju ke siklus II yaitu masingmasing $72 \%$ dan $88 \%$.
\end{abstract}

Program pengajaran merupakan jembatan yang menghubungkan materi berada dalam setiap tingkatan pendidikan dengan peserta didik sebagai obyek atau input pendidikan, tidak terkecuali Sekolah Dasar (SD). Program pengajaran kemudian diterjemahkan oleh guru dalam metode dan strategi pengajaran di kelas. Ini berlaku untuk semua mata pelajaran tidak terkecuali matematika. Sebagai ilmu pengetahuan yang berkaitan erat dengan teknologi maka menguasai mata pelajaran matematika merupakan salah satu langkah dalam mewujudkan sumberdaya manusia Indonesia yang berkualitas.

Beberapa hal yang terjadi selama pembelajaran dan ini memiliki keterkaitan dengan masalah ini antara lain: pada waktu guru membahas pelajaran matematika, rata-rata peserta didik kelas dua terlihat kurang bergairah, malas, kurang adanya respon, enggan bertanya maupun memberi pendapat. Solusi nyata dalam rangka peningkatan prestasi pelajaran matematika sebenarnya bersumber dari pembelajaran yang ada di kelas, dan dalam hal ini guru memiliki peran yang amat penting. Di SDN Kepanjenkidul 2 Kecamatan Kepanjenkidul Kota Blitar, harus diakui bahwa hasil belajar peserta didik terhadap mata pelajaran matematika masih rendah, hanya 53\% yang mengalami ketuntasan belajar. Selama ini guru hanya membacakan teks buku pelajaran matematika di depan kelas dan kemudian memberikan tugas rumah bagi peserta didik.

Muatan pelajaran matematika terpadu di kelas 2 salah satunya membelajarkan operasi perkalian bilangan, yaitu bilangan dari $1-99$, dimana pada kenyataan di lapangan, sebagian besar peserta didik kelas 2 kurang memahami operasi perkalian bilangan. Mereka hanya mampu menghafal sampai dengan 50, selebihnya mereka bingung menyebut angka berapa.

319 BRILIANT: Jurnal Riset dan Konseptual Volume 2 Nomor 3, Agustus 2017 
Dari hasil observasi pada saat pembelajaran matematika khususnya materi perkalian bilangan, dari 25 siswa yang ada, hanya $40 \%$ saja yang telah memahami perkalian atau dapat dikatakan 10 anak yang telah tuntas belajar, sedangkan $60 \%$ siswa yang lain atau sejumlah 15 anak, belum memahami materi perkalian, sehingga belum tuntas belajarnya.

Rendahnya hasil belajar peserta didik pada muatan pelajaran matematika kelas dua disebabkan oleh beberapa faktor yaitu: metode mengajar guru, relasi antara guru dan murid, penghargaan, kritikan, teguran, umpan balik, dan aktivitas belajar serta minat siswa. Untuk mengatasi masalah tersebut, guru harus segera mengambil langkah-langkah pembelajaran yang tepat sesuai dengan metodologi pendidikan. Berdasarkan kondisi ini, guru terdorong untuk mencari cara praktis, sederhana, mudah, dan efektif yaitu model Problem Based Learning (PBL). PBL dapat menarik perhatian anak dari berbagai tingkat kemampuan. Pembelajaran berbasis masalah merupakan sebuah pendekatan pembelajaran yang menyajikan masalah kontekstual sehingga merangsang peserta didik untuk belajar.

Penelitian ini dilakukan untuk menjawab permasalahan bagaimanakah penerapan model Problem Based Learning dapat meningkatkan kemampuan siswa dalam memahami suatu materi pelajaran dan bagaimana peningkatan hasil belajar serta kemampuan siswa memahami materi setelah diterapkannya model Problem Based Learning.

Tujuan penelitian ini antara lain mendeskripsikan model Problem Based Learning dalam meningkatkan hasil belajar serta kemampuan memahami materi pelajaran dan untuk mengetahui peningkatan hasil belajar dan kemampuan memahami materi pelajaran setelah diterapkannya model Problem Based Learning.

Pembelajaran matematika merupakan suatu kegiatan atau upaya untuk memfasilitasi peserta didik dalam mempelajari matematika. Dalam pelaksanaan pembelajaran, tugas guru hanya sebagai fasisliator, sedangkan peserta didik aktif mengkonstruksi sendiri pengetahuan, keterampilan budaya.

Pembelajaran berbasis masalah merupakan sebuah pendekatan pembelajaran yang menyajikan masalah kontekstual sehingga merangsang peserta didik untuk belajar. Dalam kelas yang menerapkan pembelajaran berbasis masalah, peserta didik bekerja dalam tim untuk memecahkan masalah dunia nyata (real world).

Menurut Tan (dalam Rusman, 2010: 229) PBL merupakan penggunaan berbagai macam kecerdasan yang diperlukan untuk melakukan konfrontasi terhadap tantangan dunia nyata, kemampuan untuk menghadapi segala sesuatu yang baru dan kompleksitas yang ada.

Boud dan Felleti (1991, dalam Saptono, 2003) mengungkapkan bahwa "Problem Based Learning is a way of constructing and teaching course using problem as a stimulus and focus on student activity". PBL menggunakan masalah sebagai langkah awal dalam mengumpulkan dan mengintegrasikan pengetahuan baru (Suradijono, 2004)

Berdasarkan pendapat pakar-pakar tersebut maka dapat disimpulkan bahwa Problem Based Learning (PBL) merupakan metode pembelajaran yang mendorong siswa untuk mengenal cara belajar dan bekerjasama dalam kelompok untuk mencari penyelesaian masalah-masalah di dunia nyata. Simulasi masalah digunakan untuk mengaktifkan keingintahuan siswa sebelum mulai mempelajari

320 BRILIANT: Jurnal Riset dan Konseptual Volume 2 Nomor 3, Agustus 2017 
suatu subyek. PBL menyiapkan siswa untuk berpikir secara kritis dan analitis, serta mampu untuk mendapatkan dan menggunakan secara tepat sumber-sumber pembelajaran.

Sehingga dapat diasumsikan bahwa dengan PBL siswa dirangsang untuk mempelajari masalah berdasarkan pengetahuan dan pengalaman yang telah mereka punyai sebelumnya (prior knowledge) sehingga dari prior knowledge ini akan terbentuk pengetahuan dan pengalaman baru. PBL merupakan satu proses pembelajaran di mana masalah merupakan pemandu utama ke arah pembelajaran tersebut. Dengan demikian, masalah yang ada digunakan sebagai sarana agar peserta didik dapat belajar sesuatu yang dapat menyokong keilmuannya.

Pada saat pelaksanaan menggunakan Problem Based Learning, guru harus mengikuti fase-fasenya. Lima fase yang telah dilalui yaitu : Pertama pengajuan permasalahan. Soal yang diajukan seperti dinyatakan sebelumnya harus tidak terstrktur dengan baik, dalam arti untuk penyelesaiannya diperlukan informasi atau data lebih lanjut, memungkinkan banyak cara atau jawaban, dan cukup luas kandungan materinya. Kedua, Apa yang diketahui diketahui dari permasalahan? Dalam fase ini setiap anggota akan melihat permasalahan dari segi pengetahuan yang telah dimiliki sebelumnya. Kelompok akan mendiskusikan dan menyepakati batasan-batasan mengenai permasalahan tersebut, serta memilah isu-isu dan aspek-aspek yang cukup beralasan untuk diselidiki lebih lanjut. Analisis awal ini harus menghasilkan titik awal untuk penyelidikan dan dapat direvisi apabila suatu asumsi dipertanyakan atau informasi baru muncul kepermukaan. Ketiga, Apa yang tidak diketahui dari permasalahan? Dalam fase ini, anggota kelompok akan mengurai permasalahan menjadi komponenkomponen, mendiskusikan implikasinya, mengajukan berbagai penjelasan atau solusi, dan mengembangkan hipotesis kerja. Keempat, Alternatif Pemecahan. Dalam fase ini anggota kelompok akan mendiskusikan, mengevaluasi, dan mengorganisir hipotesis dan mengubah hipotesis. Kelompok akan membuat daftar "Apa yang harus dilakukan?" Dalam fase ini anggota kelompok akan menentukan dan mengalokasikan tugas-tugas, mengembangkan rencana untuk mendapatkan informasi yang dibutuhkan. Kelima, Laporan dan Presentasi Hasil. Pada fase ini, setiap kelompok akan menulis laporan hasil kerja kelompoknya. Dalam fase laporan ini terdapat pengembangan materi, yaitu guru akan mengembangkan materi yang akan dipelajari lebih lanjut dan mendalam dan memfasilitasi pembelajaran berdasarkan konsep-konsep yang diajukan oleh setiap kelompok dalam laporannya.

Kelebihan Model PBL Menurut (Warsono dan Hariyanto, 2012, 152) kelebihan PBL antara lain : a. Siswa akan terbiasa menghadapi masalah (problem posing) dan tertantang untuk menyelesaikan masalah tidak hanya terkait dengan pembelajaran di kelas tetapi juga menghadapi masalah yang ada dalam kehidupan sehari-hari (real world). b. Memupuk solidaritas sosial dengan terbiasa berdiskusi dengan teman-teman. c. Makin mengakrabkan guru dengan siswa. d. Membiasakan siswa melakukan eksperimen.

Kelemahan dari penerapan model ini antara lain : a. Tidak banyak guru yang mampu mengantarkan siswa kepada pemecahan masalah. b. Seringkali memerlukan biaya yang mahal dan waktu yang panjang. c. Aktivitas siswa di luar sekolah sulit dipantau.

321 BRILIANT: Jurnal Riset dan Konseptual Volume 2 Nomor 3, Agustus 2017 
Menurut Ibrahim dan Nur (dalam Rusman, 2010 : 243) mengemukakan bahwa langkah-langkah PBL adalah sebagai berikut. a) Orientasi siswa pada masalah. Guru menjelaskan tujuan pembelajaran, menjelaskan logistik yang diperlukan, dan memotivasi siswa terlibat pada aktivitas pemecahan masalah. b) Mengorganisasi siswa untuk belajar. Guru membantu siswa mendefinisikan dan mengorganisasikan tugas belajar yang berhubungan dengan masalah tersebut. c) Membimbing pengalaman individual/ kelompok. Guru mendorong siswa untuk mengumpulkan informasi yang sesuai, melaksanakan eksperimen untuk mendapatkan penjelasan dan pemecahan masalah. d) Mengembangkan dan menyajikan hasil karya. Guru membantu siswa dalam merencanakan dan menyiapkan karya yang sesuai seperti laporan, dan membantu mereka untuk berbagi tugas dengan temannya. e) Menganalisis dan mengevaluasi proses pemecahan masalah. Guru membantu siswa untuk melakukan refleksi atau evaluasi terhadap penyelidikan mereka dan proses yang mereka lakukan.

\section{METODE}

Pendekatan yang digunakan dalam penelitian ini adalah pendekatan kualitatif. Sedangkan jenis penelitian yang digunakan dalam penelitian ini adalah penelitian tindakan kelas (Classroom Action Research) yaitu sebuah kegiatan penelitian yang dilakukan di kelas (Arikunto, 2007: 2). Penelitian ini dilakukan untuk memecahkan permasalahan yang muncul saat pembelajaran berlangsung. Selain itu juga menggambarkan bagaimana suatu teknik pembelajaran diterapkan, serta bagaimana hasil yang diinginkan dapat dicapai.

Rancangan penelitian yang digunakan dalam penelitian ini mengacu pada model Kemmis dan M.C. Taggart yang terdiri dari 4 tahap yaitu: perencanaan, pelaksanaan tindakan, observasi, dan refleksi. Peneliti bertindak sebagai perancang tindakan sekaligus pelaksana tindakan, artinya peneliti membuat rancangan pembelajaran selama berlangsungnya penelitian kemudian melaksanakan pembelajaran di kelas.

Dalam penelitian ini, peneliti bekerjasama dengan mitra peneliti yaitu teman sejawat dan guru mata pelajaran matematika. Teman sejawat bertugas mengambil gambar pada saat kegiatan pembelajaran berlangsung. Sedangkan guru mata pelajaran bertugas sebagai pengamat (observer).

Penelitian ini bertempat di SDN Kepanjenkidul 2 Kecamatan Kepanjenkidul Kota Blitar yang beralamat di Jalan Veteran No. 90 Kota Blitar. SDN Kepanjenkidul 2 terletak di tepi jalan raya yang sangat padat aktivitasnya, sehingga lalu lintas di depan sekolah terasa bising dan sangat menganggu kegiatan belajar mengajar. Subjek penelitian pada penelitian ini adalah siswa kelas 2 SDN Kepanjenkidul 2 Kota Blitar tahun ajaran 2015/2016 dengan jumlah siswa sebanyak 25 siswa.

Dalam penelitian ini pengumpulan data dilakukan dengan menggunakan 3 cara, yaitu observasi, tes, dokumentasi, dan catatan lapangan. Observasi dilakukan pada saat proses pembelajaran berlangsung dengan menggunakan instrumen berupa lembar observasi. Tes merupakan salah satu cara untuk mengetahui tingkat penguasaan siswa (secara individu) terhadap materi yang telah dipelajari. Instrumen yang digunakan berupa lembar tes. Tes dilakukan untuk memperoleh data tentang kemampuan siswa dalam menerapkan konsep pada saat pelaksanaan model pembelajaran Problem Based Learning. Dokumentasi berupa

322 BRILIANT: Jurnal Riset dan Konseptual Volume 2 Nomor 3, Agustus 2017 
foto-foto tentang pelaksanaan kegiatan pembelajaran pada tahap tindakan. Foto digunakan untuk mendukung data-data yang diperoleh yaitu data tentang pelaksanaan pembelajaran dan data tentang aktivitas siswa. Catatan lapangan dibuat oleh observer pada saat mengadakan observasi. Catatan lapangan digunakan sebagai data pendukung untuk melengkapi hasil observasi selama kegiatan pembelajaran menggunakan model pembelajaran PBL. Catatan lapangan berisi hal- hal penting, kekurangan, dan penyimpangan yang mungkin terjadi di luar dugaan selama proses pembelajaran.

Teknik analisis data yang digunakan dalam penelitian ini adalah teknik analisis data deskriptif dari data kuantitatif dan kualitatif. Data kuantitatif diperoleh dari hasil tes formatif siswa siklus I dan siklus II. Tujuannya untuk mengetahui kemampuan siswa dalam menerapkan konsep. Dalam penelitian ini, kriteria ketuntasan minimal (KKM) untuk matapelajaran matematika adalah 65 . Sedangkan ketuntasan belajar klasikal adalah $85 \%$. Tetapi untuk sementara, target pencapaian kemampuan menerapkan konsep secara klasikal pada siklus I 60\%, dan siklus II $70 \%$.

Data kualitatif diperoleh dari data observasi tentang pelaksanaan pembelajaran. Data-data tersebut dianalisis dengan menggunakan teknik deskriptif. Hasil analisis data dijadikan dasar untuk menentukan keberhasilan pelaksanaan tindakan kemudian dijadikan sebagai dasar untuk pelaksanaan tindakan selanjutnya.

\section{HASIL}

\section{Siklus I}

Hasil pengamatan aktivitas guru pada Siklus I pertemuan ke-1 telah memunculkan tiga aspek dari sepuluh aspek yang diamati yaitu guru telah menggali informasi awal siswa, memberikan soal-soal konsep kepada siswa dan melakukan refleksi. Pada pertemuan ke-2 kemampuan guru telah meningkat dengan bertambah dua aspek yang muncul yaitu guru telah membagi kelompok dan membimbing siswa dalam mengerjakan soal matematika.

Hasil tes tulis secara individu siklus I pertemuan ke-1 menunjukkan ratarata sebesar 71 dan meningkat pada pertemuan ke-2 menjadi 78. Sebanyak 17 siswa telah tuntas dan 8 siswa belum tuntas. Pada pertemuan ke-2 jumlah tersebut meningkat menjadi 19 siswa tuntas dan 5 siswa belum tuntas.

\section{Siklus II}

Hasil pengamatan aktivitas guru pada Siklus II pertemuan ke-1 telah meningkat dengan tujuh aspek telah muncul yaitu menggali pengetahuan awal siswa, membagi siswa menjadi beberapa kelompok belajar, Guru membimbing siswa (tiap kelompok) dalam melakukan pengamatan, memberi kesempatan kepada siswa untuk menanggapi hasil temuan kelompok lain, memberikan pertanyaan-pertanyaan yang berkaitan dengan penerapan konsep dalam kehidupan sehari-hari siswa, membimbing siswa dalam melakukan menyelesaikan masalah yang berkaitan dengan penerapan konsep, melakukan refleksi dan memberikan tindak lanjut dari kegiatan pembelajaran yang telah dilaksanakan. Pada pertemuan ke-2 kemampuan guru telah meningkat dengan bertambah semua aspek telah muncul. 
Hasil tes tulis secara individu siklus II pertemuan ke-1 menunjukkan rata-rata sebesar 80 dan meningkat pada pertemuan ke-2 menjadi 92 . Sebanyak 20 siswa telah tuntas pada pertemuan ke-1 dan 21 siswa telah tuntas pada pertemuan ke-2.

\section{PEMBAHASAN}

Setelah dilakukan tindakan pada siklus I dengan dua pertemuan maka terlihat bahwa siswa kelas 2 SDN Kepanjenkidul 2 telah dapat menentukan operasi perkalian bilangan dengan cukup baik. Artinya, peserta didik sudah mulai bisa memahami konsep operasi perkalian bilangan menggunakan media yang ada di sekitar mereka. Mereka tidak kesulitan dalam menentukan berbagai macam bentuk operasi perkalian bilangan yang diberikan oleh guru.

Langkah-langkah pembelajaran dalam pelaksanaan siklus I dan siklus II secara garis besar meliputi tahap pendefinisian masalah yaitu fasilitator menyampaikan skenario atau permasalahan dan peserta didik melakukan berbagai kegiatan brainstorming dan semua anggota kelompok mengungkapkan pendapat, ide, dan tanggapan terhadap skenario secara bebas, sehingga dimungkinkan muncul berbagai macam alternatif pendapat. Kemudian pembelajaran mandiri, peserta didik mencari berbagai sumber yang dapat memperjelas isu yang sedang diinvestigasi. Sedangkan pada kegiatan tahap investigasi memiliki dua tujuan utama, yaitu: (1) agar peserta didik mencari informasi dan mengembangkan pemahaman yang relevan dengan permasalahan yang telah didiskusikan di kelas, dan (2) informasi dikumpulkan dengan satu tujuan yaitu dipresentasikan di kelas dan informasi tersebut haruslah relevan dan dapat dmatematika hami. Pada tahap pertukaran pengetahuan, peserta didik berdiskusi dalam kelompoknya untuk mengklarifikasi capaiannya dan merumuskan solusi dari permasalahan kelompok. Pertukaran pengetahuan ini dapat dilakukan dengan cara peserrta didik berkumpul sesuai kelompok dan fasilitatornya. Pada tahap penilaian dilakukan dengan memadukan tiga aspek pengetahuan (knowledge), kecakapan (skill), dan sikap (attitude). Penilaian terhadap penguasaan pengetahuan yang mencakup seluruh kegiatan pembelajaran yang dilakukan dengan melakukan penilaian di akhir kegiatan pembelajaran

Secara umum, langkah-langkah pembelajaran yang dilaksanakan dalam pelaksanaan siklus I dan siklus II disesuaikan dengan langkah-langkah pembelajaran menggunakan model pembelajaran PBL seperti yang diungkapkan oleh (Johnston, dalam Kamdi, 2007:97) yang menyatakan bahwa langkah-langkah pembelajaran model pembelajaran PBL meliputi 5 tahap yaitu: Pendefinisian Masalah (Defining the Problem), Pembelajaran Mandiri (Self Learning), Tahap investigasi (investigation), Pertukaran Pengetahuan (Exchange knowledge), Penilaian (Assessment).

Pelaksanaan pembelajaran menggunakan model pembelajaran PBL pada siklus II mengalami peningkatan daripada siklus I. Pada pembelajaran siklus II, interaksi dan kerjasama antar siswa mulai merata, siswa mulai terlibat aktif dalam kegiatan pembelajaran. Dengan demikian penggunaan model pembelajaran PBL dapat memberikan pengalaman langsung kepada siswa. Hal ini sesuai dengan pendapat dari Ibrahim dan Nur (2000:2 dalam Nurhadi dkk,2004) bahwa pembelajaran berbasis masalah digunakan untuk merangsang berpikir tingkat tinggi dengan situasi berorientasi pada masalah, termasuk didalamnya belajar

324 BRILIANT: Jurnal Riset dan Konseptual Volume 2 Nomor 3, Agustus 2017 
bagaimana belajar. Sehingga pengetahuan yang diperoleh siswa lebih melekat pada diri siswa dan penemuan-penemuan baru yang diperoleh siswa dalam kegiatan pembelajaran, dapat diterapkan siswa dalam kehidupan sehari-hari.

Peningkatan kemampuan siswa dalam menerapkan konsep pada pembelajaran matematika di kelas 2 SDN Kepanjenkidul 2 Kota Blitar dapat diketahui dari nilai hasil evaluasi pada tahap pratindakan, siklus I dan siklus II. Setelah dilakukan tindakan pada siklus I dengan dua pertemuan maka terlihat bahwa siswa kelas 2 SDN Kepanjenkidul 2 telah dapat menentukan operasi perkalian bilangan dengan cukup baik. Artinya, peserta didik sudah mulai bisa memahami konsep operasi perkalian bilangan menggunakan media yang ada di sekitar mereka. Mereka tidak kesulitan dalam menentukan berbagai macam bentuk operasi perkalian bilangan yang diberikan guru.

Persentase ketuntasan belajar pada siklus I pertemuan ke-1 mencapai $68 \%$. Sedangkan pada pertemuan kedua mencapai $76 \%$. Dari hasil tersebut dapat diketahui dengan penggunaan model PBL, terjadi peningkatan hasil dan persentase ketuntasan belajar siswa pada siklus pertama. Namun demikian, hasil tersebut menunjukan bahwa pada siklus pertama peserta didik belum tuntas belajarnya, karena persentase peserta didik yang memperoleh $>65$ hanya sebesar $68 \%$ lebih kecil dari prosentase yang dikehendaki yaitu $80 \%$.

Adapun keberhasilan dan kegagalan yang terjadi pada siklus pertama adalah sebagai berikut (1) Guru kurang membimbing peserta didik dalam kegiatan pembelajaran, (2) Guru kurang memanfaatkan waktu seefisien mungkin, (3) Sebagian peserta didik belum terbiasa dengan penjumlahan dan pengurangan, sehingga sedikit mengalami kesulitan, terutama pada peserta didik yang tidak memakai media belajar yang ada di sekelilingnya. (4) Hasil evaluasi pada siklus pertama mencapai rata-rata 75 .

Ketuntasan belajar siswa pada siklus II pertemuan pertama mencapai $80 \%$ dan pada pertemuan kedua mencapai $96 \%$. Adanya peningkatan hasil belajar peserta didik dipengaruhi oleh adanya kemampuan guru dalam membimbing dan memotivasi peserta didik sehingga peserta didik bisa menentukan operasi perkalian bilangan.

Adapun keberhasilan dan kegagalan yang terjadi pada siklus kedua baik pada pertemuan pertama maupun pertemuan kedua adalah sebagai berikut. (1) Selama proses pembelajaran guru telah melaksanakan pembelajaran dengan baik meskipun masih ada beberapa aspek yang belum sempurna, tetapi persentase pelaksanaannya untuk masing-masing aspek sudah cukup besar. Hal itu terbukti dari peningkatan nilai rata-rata dari 80 menjadi 92 dan peningkatan ketuntasan belajar dari $80 \%$ menjadi $96 \%$, (2) berdasarkan data hasil pengamatan diketahui bahwa peserta didik sangat aktif selama proses belajar mengajar berlangsung, (3) kekurangan pada siklus-siklus sebelumnya sudah mengalami perbaikan dan peningkatan menjadi lebih baik.

Peningkatan hasil belajar siswa pada siklus II pada dasarnya sangat terpengaruh oleh peran guru sebagai fasilitator dan motivator. Seperti yang diungkap oleh Mulyasa (2006) yang menjelaskan bahwa untuk mendukung siswa mencapai keberhasilan dalam belajar, guru perlu memperhatikan beberapa hal yaitu: (1) mengurangi metode ceramah, (2) mengelompokkan siswa sesuai dengan kemampuannya, (3) memberikan tugas yang berbeda bagi setiap siswa, (4) bahan pelajaran harus dimodifikasi dan diperkaya, (5) menggunakan prosedur yang 
bervariasi, (6) menciptakan situasi belajar yang dapat mengembangkan kemampuan anak untuk bekerja sama, dan (7) melibatkan siswa dalam berbagai kegiatan. Dengan demikian, dalam pelaksanaan pembelajaran hendaknya siswa dilibatkan secara aktif agar kegiatan pembelajaran yang dialami oleh siswa lebih bermakna.

Dengan demikian keberhasilan kegiatan pembelajaran matematika di kelas 2 SDN Kepanjenkidul 2 Kota Blitar telah membuktikan bahwa penerapan model pembelajaran PBL mempunyai beberapa kelebihan seperti yang diungkapkan oleh Soebagio (dalam Kamdi, 2007:100) yang menyatakan bahwa "kelebihan model pembelajaran PBL adalah: (1) meningkatkan motivasi belajar karena siswa dilibatkan secara aktif dalam proses pembelajaran, (2) membantu mengembangkan sikap ilmiah siswa, (3) pembelajaran menjadi lebih bermakna. Untuk lebih jelasnya peningkatan kemampuan serta hasil belajar dapat digambarkan pada diagram berikut.

\section{KESIMPULAN}

Berdasarkan hasil penelitian dan pembahasan tentang penerapan model pembelajaran PBL pada pembelajaran matematika di kelas 2 SDN Kepanjenkidul 2 Kota Blitar, dapat disimpulkan hal-hal sebagai berikut: (1) Langkah-langkah pembelajaran dalam pelaksanaan siklus I dan siklus II secara garis besar meliputi: tahap pendefinisian masalah, pembelajaran mandiri, investigasi, pertukaran pengetahuan, dan penilaian. Pada tahap penilaian Penilaian dilakukan dengan memadukan tiga aspek pengetahuan (knowledge), kecakapan (skill), dan sikap (attitude). Penilaian terhadap penguasaan pengetahuan yang mencakup seluruh kegiatan pembelajaran yang dilakukan dengan melakukan penilaian di akhir kegiatan pembelajaran. (2) Kemampuan siswa kelas 2 dalam menerapkan konsep pada tahap pratindakan belum mencapai keberhasilan dengan ketuntasan belajar siswa dalam mengerjakan soal-soal penerapan konsep hanya sebesar $40 \%$. Penerapan model pembelajaran PBL pada pembelajaran matematika dapat meningkatkan kemampuan siswa dalam menerapkan konsep. Hal ini terlihat dari perolehan nilai rata-rata siswa yang mengalami peningkatan secara bertahap mulai dari pratindakan, siklus I dan siklus II yaitu masing-masing $40 \%, 72 \%$, dan $88 \%$.

\section{SARAN}

Berdasarkan penelitian yang telah dilaksanakan, terdapat beberapa saran yaitu: Guru mempunyai peranan penting dalam keberhasilan belajar siswa. Oleh karena itu hendaknya guru mampu menciptakan suasana pembelajaran yang menarik perhatian siswa, baik berupa pemecahan masalah maupun berupa proses penemuan sehingga siswa mempunyai pengalaman langsung yang dapat diterapkan dalam kehidupan sehari-hari. Guru perlu mengembangkan pertanyaanpertanyaan yang berhubungan dengan pengalaman siswa dalam kehidupan seharihari sehingga apabila dihadapkan dengan soal-soal penerapan konsep, siswa tidak merasa kesulitan. Guru dapat menerapkan model pembelajaran PBL pada mata pelajaran lain dalam rangka meningkatkan kemampuan siswa dalam menerapkan konsep yang telah dipelajari.

326 BRILIANT: Jurnal Riset dan Konseptual Volume 2 Nomor 3, Agustus 2017 


\section{DAFTAR RUJUKAN}

Arikunto, Suharsimi. 2007. Penelitian Tindakan Kelas. Jakarta: PT. Bumi Aksara. Depdikbud. 2002. Pendekatan Kontekstual. Jakarta: Balai Pustaka.

Dunne \&Ted Wragg, 1996. Pembelajaran Aktif dan Efektif. Jakarta: Grasindo.

Mulyasa, E. 2006. Menjadi Guru Profesional Menciptakan Pembelajaran Kreatif dan Menyenangkan. Bandung: PT. Remaja Rosdakarya.

Kamdi, Waras. 2007. Model-Model Pembelajaran Inovatif. Malang: Universitas Negeri Malang.

Nurhadi, Senduk. 2000. Model Pembelajaran Inovatif. Bandung: Remaja Rosdakarya

Rusman, D., \& Pd, M. 2010. Model-model Pembelajaran Mengembangkan Profesionalisme Guru. Jakarta: PT. Raja Grafindo Persada.

Saptono, S. (2003). Strategi belajar mengajar biologi. Semarang: Universitas Negeri Semarang.

Suradijono, S. H. R. 2004. Problem-based learning: Apa dan bagaimana. In Makalah Seminar" Penumbuhan Inovasi Sistem Pembelajaran: Pendekatan Problem-Based Learning berbasis ICT (Information and Communication Technology) (Vol. 15, No. 5, p. 2004). 